\title{
IMPACT OF COVID-19 ON HUMAN HEALTH AND ECONOMY: AN EMPIRICAL STUDY BASED ON THREAT PERCEPTION VARIANCE AMONG SEVERAL DEMOGRAPHIC GROUPS IN INDIA
}

\author{
Shounak Das ${ }^{1}$, Rohan Prasad Gupta ${ }^{2}$ \\ ${ }^{1}$ State Aided College Teacher- Category 1, Department of Commerce, Vivekananda College, Kolkata, \\ West Bengal \\ ${ }^{2}$ Research Scholar, JRF, Department of Commerce, University of Calcutta
}

Article DOI: $\underline{\text { https://doi.org/10.36713/epra7376 }}$ DOI No: 10.36713/epra7376

\begin{abstract}
The entire world is passing through great uncertainty due to the spread of the COVID-19 pandemic. There are, primarily, two major visible threats that the world is facing at this juncture. One is on the health of the masses and other one is on the economy. In Indian context majority of the socio-economic activities are under complete and partial lockdown for several months, since March 25, 2020 and restrictions has been eased in phased manner. This has affected the lives of almost all, especially the poor and marginalized population, agricultural labourers, and the informal sector workforce. India needs to be more proactive and planned when it comes to countering the social and economic effects of any pandemic in future. In this context, it is of equal importance to observe the threat perception prevailing among people belonging to different demographic groups. Threat perception is a serious aftershock of any pandemic that restricts general public in returning to their normal socioeconomic life. It has huge socio-economic back fall. Under this study, the researchers have used survey method to collect primary data on the threat perception of people coming from different demographic groups. The study focus to identify whether there is any variation in threat perception of people regarding COVID-19 pandemic with reference to several demographic groups. To analyze the variation among different demographic groups Kruskal-Wallis Test, popularly known as the H-Test, is used. Henceforth, Post- Hoc Test is also performed to identify the significant differences in threat perception among different pair of sub groups, where demographic factors significantly impact threat perception. The researchers have also conducted Ordinal Logistic Regression to identify the level of variation in dependent variable, explained by independent variables. The variation in threat perception among peoples regarding this disease will definitely have huge impact on their socio-economic lifestyles. The research shows mixed results. The researchers have also suggested some recommendations based on the results of the study to control or rather to bridge up threat perceptional variations regarding COVID-19 for protecting socio-economic backbone of the country.
\end{abstract}

KEYWORDS: Covid-19, Kruskal-Wallis Test, Lockdown, Ordinal Logistic Regression, Pandemic, Post- Hoc Test, Threat perception.

JEL Classification: C12, C14, C31, C83, C87, C88, Y10. 


\section{RESEARCH PROBLEM}

Almost all the countries across the globe are in the middle phase of spread of Covid-19 pandemic. This devastating pandemic is inflicting two major traumas on the all nations, one is on the health of the population and the other one is obviously on the economy. Given, the newly born disease, which is highly contagious in nature, the ways to contain the spread includes various policy actions such as imposition of complete lockdown to phase wise starting of social and economic activities, social distancing, quarantine; that is, selfisolation at home and many more. These actions, which are followed by almost all the nation states, will potentially lead to dire consequences for economies around the world. The containment of this virus requires restricting the normal functioning of social and economic activities which has triggered fears of a deep and prolonged global recession. In Indian context, to curb the spread of this contagious disease, the Government of India announced a nationwide complete lockdown for three weeks commencing from March 25, 2020. Afterwards several restrictions were already removed in a phased manner to revive the economy. The nationwide lockdown has an adverse impact on the mental, social and economic health of the nation and hence it has far reaching impact on restarting the normal business cycle in full-fledged manner to boost the Indian economy. In this context, it is also significant to deeply peep into the thought process of the masses, that is, the threat perception of the people regarding this pandemic. Threat perception is an individual's cognitive assessment of the likelihood a danger will affect them. In this economic opening up situation, the extensive study of variation in threat perception of people regarding COVID-19 pandemic will reveal the readiness among people to unlock themselves and to contribute their efficiency for pushing the wheel of economic growth. Hence, in this current scenario, it is of utmost importance for social science researchers of the country to conduct in depth and extensive study about the variation in threat perception among the people belonging to different demographic groups with respect to this pandemic. This has socio-economic implication on individuals' livelihood and on economic prospects of the country. Amidst this lockdown situation, one major issue which has aroused is of migrant workers belonging to different sectors, especially from MSME sector. The workers working in different states are gradually returning to their native places due to loss of job and inadequacy of means of survival. Post lockdown, the willingness of these migrants to return to their respective workplaces will depend on their threat perception regarding this disease. Moreover, general threat from the disease induces the general public to avoid physical shops and goes for online. This creates major sustainability problems for many small and medium shops dealing in essential items, luxury items and durable items. It is of general importance to identify which demographic groups have higher or lower threat perception and to take desired precautions so that too much threat does not restrict normal movements as far as possible and too less threat induces the spread of infection through careless actions. Both have tremendous socio-economic significance.

\section{LITERATURE REVIEW}

There are very few literatures available on this area of research ranging from research work to various news reports because of the limited timeframe available. The researcher has gone through several existing literatures in this area and some of them are as follows.

Roy, D., Tripathy, S., Kar, S., Sharma, N. \& Kaushal, V. (2020). The study titled 'Study of knowledge, attitude, anxiety \& perceived mental healthcare need in Indian population during COVID-19 pandemic' concluded that most of the educated people and health professionals are aware of this infection, possible preventive measures, the importance of social distancing and government initiatives were taken to limit the spread of infection. However, people have higher perceived needs to deal with their mental health difficulties. There is a need to intensify the awareness program and address the mental health issues of people during this COVID-19 pandemic. Bavel, J., Baiker, K. \& Willer, R. (2020). This study named 'Using social and behavioral science to support COVID-19 pandemic response' focus on the behavioral aspect of the pandemic, risk perception of the masses, social and cultural shifts, emotional impact, discrimination and prejudices related to this disease. Dey, P. (2020). The study named 'COVID-19, New Normal and India' concludes that this is the time of a medical emergency. Crisis time calls for togetherness and partnership. Countries have to work together while dealing with the crisis, particularly for the post-crisis recovery. India's advantage is its leadership. Stable and strong leadership is in command. No event better demonstrates why a stronger network between countries is so vital to design a strategy for the entire world. Gupta, R., Pal, K. \& Pandey, G. (2020). The research work titled 'A Comprehensive Analysis of COVID-19 Outbreak situation in India' depicts that the cases are rising very 
fast and they need aggressive control strategies from the administrative units of India. The study relates to presenting the growth trends of infected cases in India, predictions for the number of infected cases for next few days, impact of social distancing on the citizens of India, impact of mass events on the number of infected cases in India, network analysis and mining of patterns regarding the patients suffering from corona virus, and analyzing the strategies for uplifting lockdown in India.

Hindustan Times, May 7, 2020: The social and economic fissures exposed by the pandemic will result in mass unemployment, depleted social safety nets, starvation, increase in gender-based violence, homelessness, alcoholism, loan defaults and millions slipping into poverty. This post-Covid-19 landscape will be a fertile breeding ground for an increase in chronic stress, anxiety, depression, alcohol dependence, and self-harm.

\section{RESEARCH GAP}

Based on the extensive review of the available literature, the researchers have identified that there is no definite study on the threat perception variation regarding corona virus disease among different demographic groups. The researchers consider that such research work having huge socio-economic significance needs to be undertaken and identifies it as a research gap. The behavioral study, which is sociopsychological in nature, not only focuses to dig out that whether there is any variance in threat perception among people belonging to various demographic groups regarding this pandemic by the use of survey method but also to extend the study to find out the socio-economic implications of such variance. Socioeconomic significance lies in finding and alleviating the threat perceptional variances and thereby restarting the economic activities in the country in a full-fledged manner.

\section{RESEARCH OBJECTIVES}

The study is intensified on the following research objectives based on the above research gap:

1. To identify whether there is any variation in threat perception among people regarding COVID-19 pandemic with reference to area of stay.

2. To identify whether there is any variation in threat perception among people regarding COVID-19 pandemic among different age groups.

3. To identify whether there is any variation in threat perception among people regarding
COVID-19 pandemic with respect to educational level.

4. To identify how many these demographic variables can explain the variation in the threat perception among people.

5. To identify whether such variation has any economic impact and to suggest for some possible solutions to control such variation for smooth functioning of economic activities.

\section{RESEARCH QUESTIONS}

Based on above research objectives following research questions have been formulated by the researchers:

1. Does the threat perception of people regarding COVID-19 pandemic varies from area to area?

2. Does the threat perception of people regarding COVID-19 pandemic varies among different age groups?

3. Does the threat perception of people regarding COVID-19 pandemic varies with respect to level of education?

4. How much the demographic variables can explain the variation in the threat perception among people?

5. Does the variation in threat perception of people regarding COVID-19 pandemic has any serious economic impact?

\section{RESEARCH HYPOTHESIS}

To answer the above research questions and to fulfill the above research objectives, the following research hypothesis has been derived:

1. $\mathrm{H}_{\mathrm{o} 1}$ : There exists no significant variation in threat perception among people with respect to area of stay.

2. $\mathrm{H}_{\mathrm{o} 2}$ : There exists no significant variation in threat perception among people among having different age groups.

3. $\mathrm{H}_{03}$ : There exists no significant variation in threat perception among people with respect to level of education.

4. $\mathrm{H}_{04}$ : The regression model does not provide good prediction of the outcomes.

5. $\mathrm{H}_{05}$ : The predicted values are consistent with observed values for the regression model.

6. $\mathrm{H}_{06}$ : The location parameters (slope coefficients) are the same across response categories.

\section{RESEARCH METHODOLOGY}

The researchers have conducted this study based on data collected through primary survey, to fulfill the 
above research objectives. Total 230 samples have been collected from various locations of West Bengal, Jharkhand and Uttar Pradesh, both by sending the questionnaire in online form and also by directly interviewing the respondents. A questionnaire was prepared through Google Form application. Following information has been collected from general people.

1. Name of the respondents (optional).

2. Threat perception of the respondents regarding Corona on human health (mandatory and in 5 point ordinal scale).

3. Place of stay of the respondents (mandatory and in nominal scale with 3 categories).

4. Age of the respondents (mandatory and in nominal scale with 5 age groups).

5. Highest educational qualification of the respondents (mandatory and in nominal scale with 5 qualification groups).

The researchers has chosen the demographic factors based on their personal judgments regarding what factors are mostly responsible for impacting the individual's perception regarding the threat arising from the current disease on the human health. The researchers have given tabular presentations of dependent variable and independent variables separately, with absolute figures, percentage figures and cumulative percentage figures of total respondents under each sub-group of variables. Researchers have also provided tabular presentations of absolute figures and percentage figures of total respondents under different combinations of 3 independent variables with 1 dependent variable. This has been done as a part of descriptive statistics.

Total 230 samples have been collected by the researchers. The researchers have conducted nonparametric Kruskal-Wallis Test to see whether following null hypothesis has been accepted or not.

1. $\mathrm{H}_{\mathrm{o} 1}$ : There exists no significant variation in threat perception among people with respect to area of stay.
2. $\mathrm{H}_{\mathrm{0} 2}$ : There exists no significant variation in threat perception among people among having different age groups.

3. $\mathrm{H}_{03}$ : There exists no significant variation in threat perception among people with respect to level of education.

4. $\mathrm{H}_{04}$ : The regression model does not provide good prediction of the outcomes.

5. $\mathrm{H}_{05}$ : The predicted values are consistent with observed values for the regression model.

6. $\mathrm{H}_{06}$ : The location parameters (slope coefficients) are the same across response categories.

If null hypothesis got rejected Post Hoc Test has been conducted by the researchers to understand between which groups of independent variable mean threat perception differs significantly. Finally researchers conducted Ordinal Logistic Regression by taking those independent variables having significant relationship with dependent variable. Non parametric test has been used to check the variation in mean threat perception among the sub-groups of independent variables because the dependent variable is in ordinal form. Researchers have analyzed the test results in details and provide definite causes for the results through logical discussions and based on these procedures conclusions have been drawn. Finally through recommendations; researchers discussed in details how high or low threat perceptions due to demographic variations can negatively impact the normal economic activities in the country by various means and full proof measures are suggested by the researchers to counter these problems.

\section{DATA PRESENTATION AND ANALYSIS}

\section{Descriptive Statistics}

Based on the above defined Research Methodology, the researchers have gone through following procedures to fulfill the said research objectives.

Distribution of Threat Perception in the Sample (Table: 1.1)

\begin{tabular}{|c|c|c|c|}
\hline Threat Perception & Absolute Value & Percentage (\%) & Cumulative Percentage (\%) \\
\hline Very High & 114 & 49.56 & 49.56 \\
\hline High & 56 & 24.35 & 73.91 \\
\hline Moderate & 36 & 15.65 & 89.56 \\
\hline Low & 16 & 6.96 & 96.52 \\
\hline Very Low & 8 & 3.48 & 100 \\
\hline
\end{tabular}

Source: Computed by the authors based on data collected through primary survey. 
Figure: 1

\section{Threat Perception}

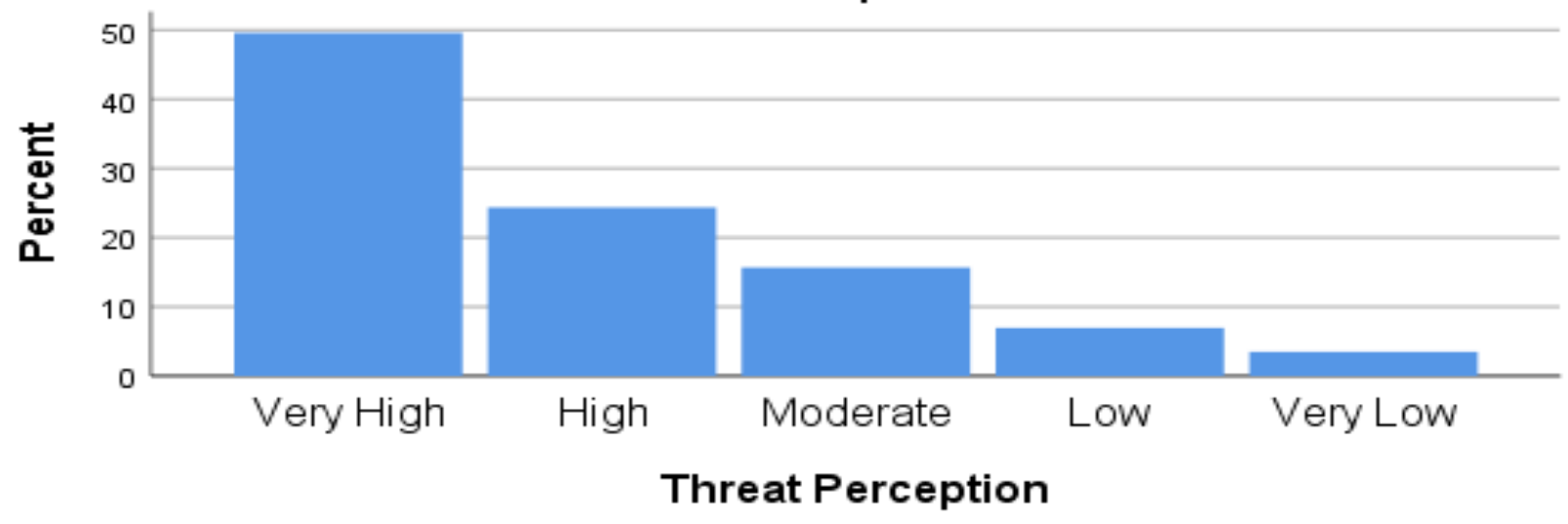

Source: Computed Through SPSS.

It is observable from table 1.1 and Figure 1 that out of total number of respondents; $114(49.56 \%)$ have very high, $56(24.35 \%)$ have high, $36(15.65 \%)$ have moderate, $16(6.96 \%)$ have low and $8(3.48 \%)$ have very low threat perceptions.

Distribution of Place of Stay in the Sample (Table: 1.2)

\begin{tabular}{|c|c|c|c|}
\hline Location & Absolute Value & Percentage (\%) & Cumulative Percentage (\%) \\
\hline Urban & 133 & 57.83 & 57.83 \\
\hline Semi-urban & 61 & 26.52 & 84.35 \\
\hline Rural & 36 & 15.65 & 100 \\
\hline
\end{tabular}

Source: Computed by the authors based on data collected through primary survey.

Figure: 2

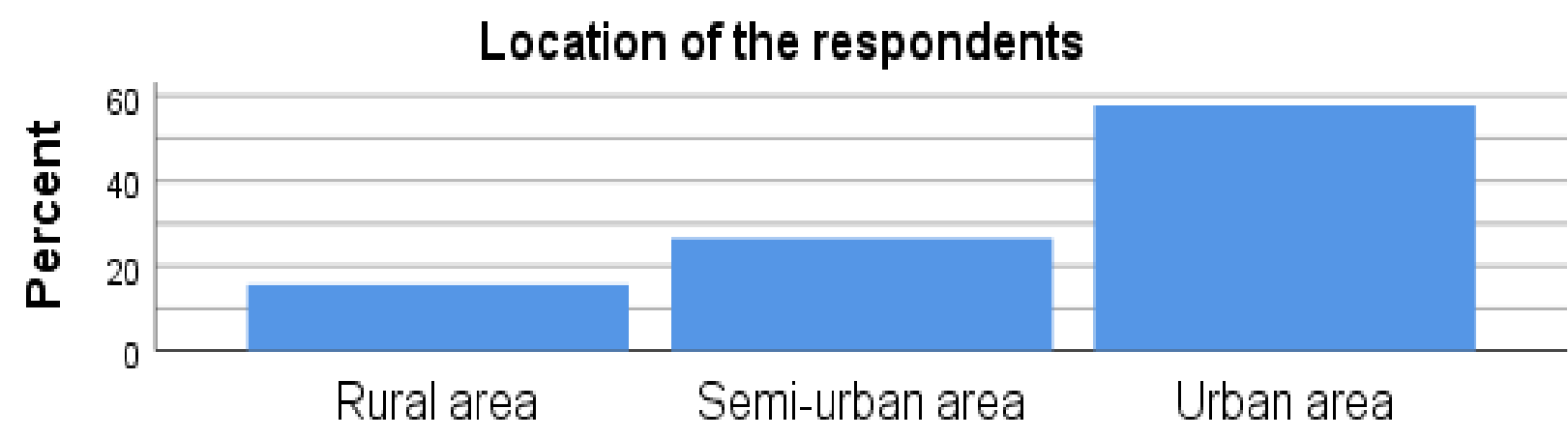

\section{Location of the respondents}

Source: Computed Through SPSS.

It is visible from table 1.2 and Figure 2 that out of total number of respondents surveyed; 133 (57.83\%) belongs to urban area, 61 (26.52\%) belongs to semiurban area and $36(15.65 \%)$ belongs to rural area. 
EPRA International Journal of Socio-Economic and Environmental Outlook (SEEO)

ISSN: 2348-4101

Volume: 8 | Issue: 6 | June 2021 | SJIF Impact Factor (2021): 7.426 | Journal DOI: 10.36713/epra0314 | Peer-Reviewed Journal

Distribution of Age Groups in the Sample (Table: 1.3)

\begin{tabular}{|c|c|c|c|}
\hline Age Groups & Absolute Value & Percentage (\%) & Cumulative Percentage (\%) \\
\hline 15-25 years & 72 & 31.31 & 31.31 \\
\hline 25-40 years & 54 & 23.48 & 54.79 \\
\hline 40-50 years & 38 & 16.52 & 71.31 \\
\hline 50-60 years & 36 & 15.65 & 86.96 \\
\hline Above 60 years & 30 & 13.04 & 100 \\
\hline
\end{tabular}

Source: Computed by the authors based on data collected through primary survey.

Figure: 3

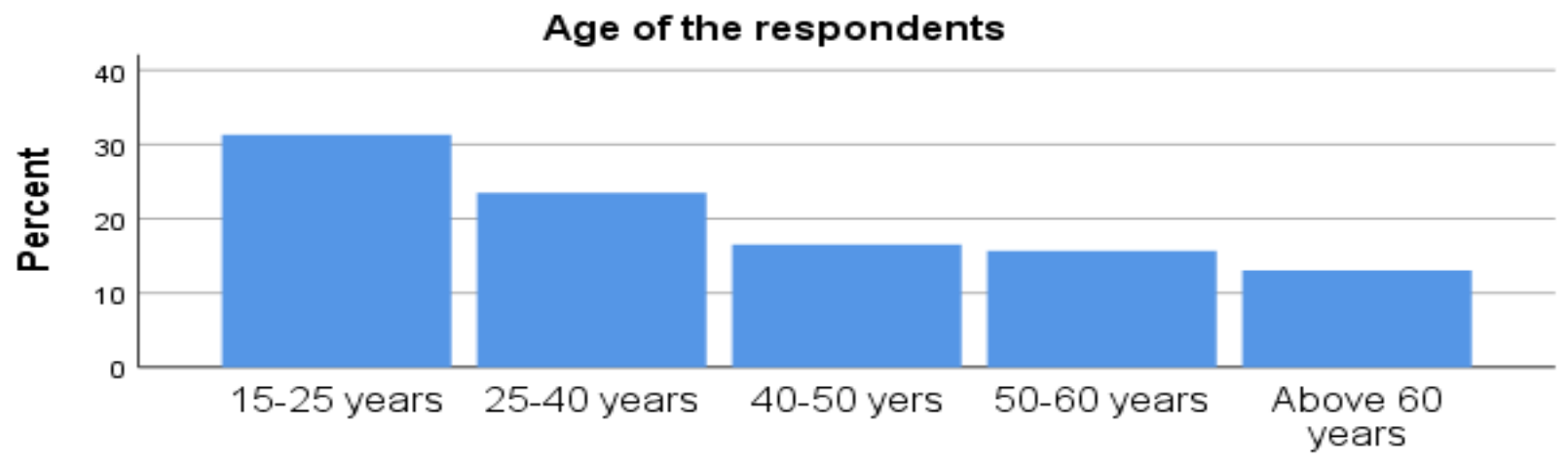

Age of the respondents

Source: Computed Through SPSS.

It is visible from table 1.3 and figure 3 that out of total number of respondents surveyed; $72(31.31 \%)$ belongs to $15-25$ years, $54(23.48 \%)$ belongs to $25-40$ years, 38
(16.52\%) belongs to $40-50$ years, 36 (15.65) belongs to $50-60$ years and $30(13.04 \%)$ belongs to above 60 years age group.

Distribution of the Qualification Groups in the Sample (Table: 1.4)

\begin{tabular}{|l|c|c|c|}
\hline \multicolumn{1}{|c|}{ Qualification } & Absolute Value & Percentage (\%) & $\begin{array}{c}\text { Cumulative Percentage } \\
\text { (\%) }\end{array}$ \\
\hline Below class 10 & 36 & 15.65 & 15.65 \\
\hline Up to 10th class & 35 & 15.22 & 30.87 \\
\hline Up to 12th class & 31 & 13.48 & 44.35 \\
\hline Up to Graduation & 80 & 34.78 & 79.13 \\
\hline Post-Graduation and above & 48 & 20.87 & 100 \\
\hline
\end{tabular}

Source: Computed by the authors based on data collected through primary survey. 
Figure: 4

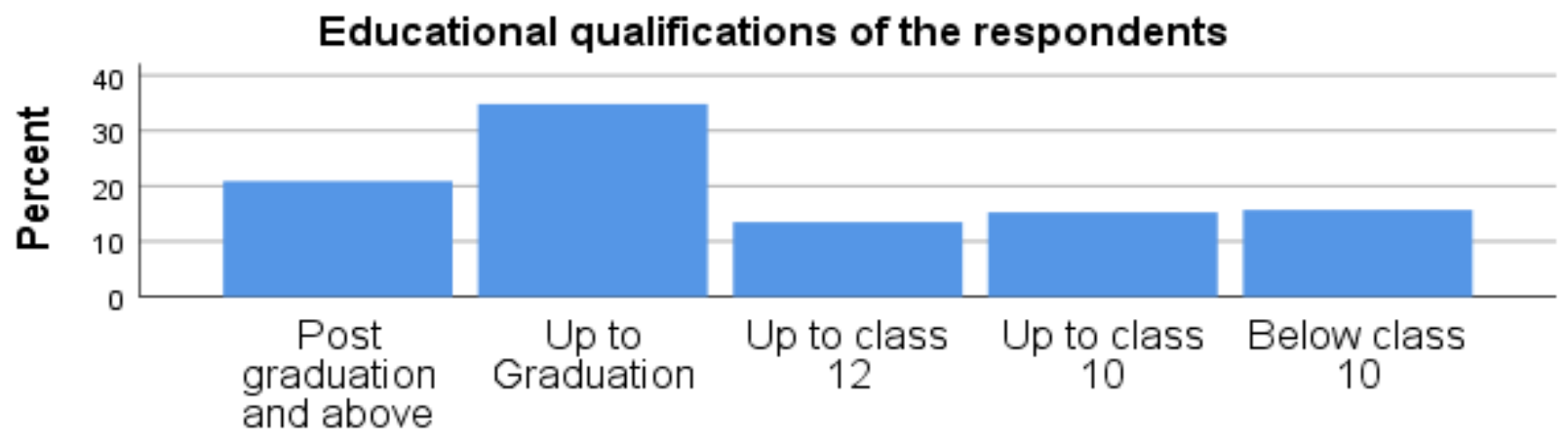

\section{Educational qualifications of the respondents}

Source: Computed Through SPSS.

It is visible from table 1.4and figure 4 that out of total number of respondents surveyed; $36(15.65 \%)$ belongs to below class $10,35(15.22 \%)$ belongs to up to 10 th class, $31(13.48 \%)$ belongs to up to 12th class, 80 (34.78\%) belongs to up to Graduation and $48(20.87 \%)$ belongs to Post Graduation and above category.

Threat Perception of the Respondents According to their Places of Stay in Absolute Figures (Table: 2.1)

\begin{tabular}{|l|c|c|c|c|c|c|}
\hline Location & Very High & High & Moderate & Low & Very Low & Total \\
\hline Urban & & & & & & \\
\hline Semi-urban & 19 & 28 & 14 & 5 & 2 & 133 \\
\hline Rural & 13 & 5 & 9 & 4 & 2 & 2 \\
\hline Total & 114 & 56 & 36 & 16 & 8 & 230 \\
\hline
\end{tabular}

Source: Computed by the authors based on data collected through primary survey.

*Threat Perception

It is being observed from the above table 2.1 that of total respondents coming from urban area; 82 have very high, 28 have high, 14 have moderate, 5 have low and 4 have very low threat perceptions. 19 have very high, 23 have high, 13 have moderate, 4 have low and 2 have very low threat perceptions, in case of respondents from semi-urban area. In case of respondents from rural area, 13 have very high, 5 have high, 9 have moderate, 7 have low and 2 have very low threat perceptions.

Percentage of Respondents Having Various Degrees of Threat Perception to the Total Numbers of Respondents Staying in Different Areas (Table: 2.2)

\begin{tabular}{|l|c|c|c|c|c|c|}
\hline Location & $\begin{array}{c}\text { Very High } \\
(\boldsymbol{\%})\end{array}$ & High (\%) & Moderate (\%) & Low (\%) & Very Low (\%) & Total (\%) \\
\hline Urban & 61.65 & 21.05 & 10.53 & 3.76 & 3.01 & 100 \\
\hline Semi-urban & 31.15 & 37.70 & 21.31 & 6.56 & 3.28 & 100 \\
\hline Rural & 36.11 & 13.89 & 25 & 19.44 & 5.56 & 100 \\
\hline
\end{tabular}

Source: Computed by the authors based on data collected through primary survey.

*Threat Perception

It is being observed from the above table 2.2 that of total respondents coming from urban area; $61.65 \%$ have very high, $21.05 \%$ have high, $10.53 \%$ have moderate, $3.76 \%$ have low and $3.01 \%$ have very low threat perceptions. $31.15 \%$ have very high, $37.70 \%$ have high, $21.31 \%$ have moderate, $6.56 \%$ have low and $3.28 \%$ have very low threat perceptions, in case of respondents from semi-urban area. In case of respondents from rural $36.11 \%$ have very high, $13.89 \%$ 
EPRA International Journal of Socio-Economic and Environmental Outlook (SEEO)

ISSN: 2348-4101

Volume: 8 | Issue: 6 | June 2021 | SJIF Impact Factor (2021): 7.426 | Journal DOI: 10.36713/epra0314 | Peer-Reviewed Journal

have high, $25 \%$ have moderate, $19.44 \%$ have low and $\quad 5.56 \%$ have very low threat perceptions.

Percentage of Respondents Staying in Different Areas to the Total Numbers of Respondents Falling Under Different Degrees of Threat Perception (Table: 2.3)

\begin{tabular}{|l|c|c|c|c|c|}
\hline Location & Very High (\%) & High (\%) & Moderate (\%) & Low (\%) & Very Low (\%) \\
\hline Urban & & & & & \\
\hline Semi-urban & 71.93 & 50 & 38.89 & 31.25 & 50 \\
\hline Rural & 16.67 & 41.07 & 36.11 & 25 & 25 \\
\hline Total (\%) & 11.40 & 8.93 & 25 & 43.75 & 25 \\
\hline
\end{tabular}

Source: Computed by the authors based on data collected through primary survey.

*Threat Perception

Table 2.3 reveals, of the total respondents having very high threat perception; $71.93 \%$ belongs to urban area, $16.67 \%$ belongs to semi-urban area and $11.40 \%$ belongs to rural area. $50 \%$ belongs to urban area, $41.07 \%$ belongs to semi-urban area and $8.93 \%$ belongs to rural area, of the total respondents having high threat perception. In case of respondents having moderate threat perception; $38.89 \%$ belongs to urban area, $36.11 \%$ belongs to semi-urban area and $25 \%$ belongs to rural area. $31.25 \%$ belongs to urban area, $25 \%$ belongs to semi-urban area and $43.75 \%$ belongs to rural area, of the total respondents having low threat perception. Out of the total respondents having very low threat perception; $50 \%$ belongs to urban area, $25 \%$ belongs to semi-urban area and $25 \%$ belongs to rural area.

\section{Inferential Statistics}

The following Null and Alternative Hypothesis has been considered for Analysis

$\mathrm{H}_{01}$ : There is no significant variation in average threat perception based on places of stay for general people. $\mathrm{H}_{11}$ : There is significant variation in average threat perception based on places of stay for general people. Analysis:

Table: 2.4

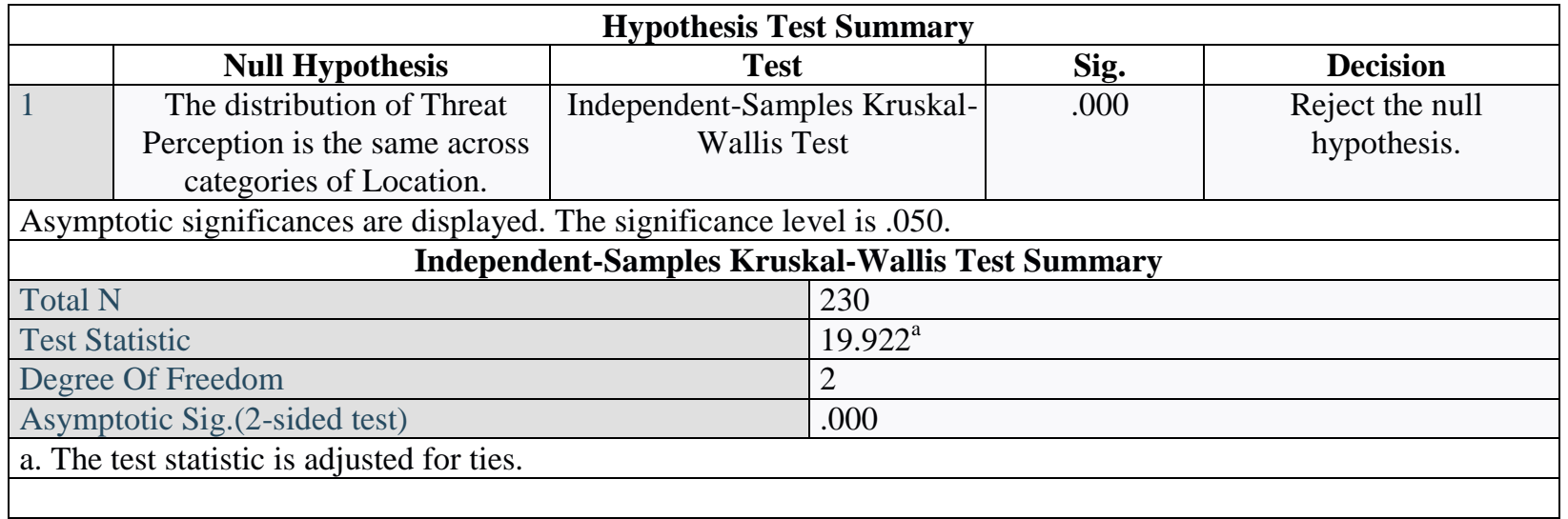

Source: Computed Through SPSS Software.

Based on the results given in the above table 2.4, it is clearly visible that null hypothesis is being rejected at $5 \%$ level of significance and at 2 degree of freedom, with a $\mathrm{P}$ value of $.000(\mathrm{P}<.050)$. Hence there is significant variation in average threat perception based on places of stay for general people. 
EPRA International Journal of Socio-Economic and Environmental Outlook (SEEO)

ISSN: 2348-4101

Volume: 8 | Issue: 6 | June 2021 | SJIF Impact Factor (2021): 7.426 | Journal DOI: 10.36713/epra0314 | Peer-Reviewed Journal

Post Hoc Test

Table: 2.5

\begin{tabular}{|l|l|l|l|l|l|}
\hline \multicolumn{7}{|c|}{ Pairwise Comparisons of Location } \\
\hline Sample 1-Sample 2 & Test Statistic & Std. Error & Std. Test Statistic & Sig. & Adj. Sig. $^{\text {a }}$ \\
\hline rural area-semi urban area & 8.669 & 12.966 & .669 & .504 & 1.000 \\
\hline rural area-urban area & 41.803 & 11.590 & 3.607 & .000 & .001 \\
\hline semi urban area-urban area & 33.134 & 9.540 & 3.473 & .001 & .002 \\
\hline $\begin{array}{l}\text { Each row tests the null hypothesis that the Sample 1 and Sample 2 distributions are the same. } \\
\text { Asymptotic significances (2-sided tests) are displayed. The significance level is .05. }\end{array}$ \\
\hline \begin{tabular}{l} 
a. Significance values have been adjusted by the Bonferroni correction for multiple tests. \\
\hline
\end{tabular}
\end{tabular}

Source: Computed Through SPSS Software.

It is being observed from the above Table 2.5 that after adjusting the significance values through Bonferroni correction for multiple tests, the statistically significant differences in mean threat perception exists between rural and urban areas and between semi urban and urban areas. The adjusted $\mathrm{P}$ value is .001 and .002 for rural area-urban area and semi urban area-urban area respectively and both the valuesare less than .050 . No significant difference exists in other combination.

Figure: A

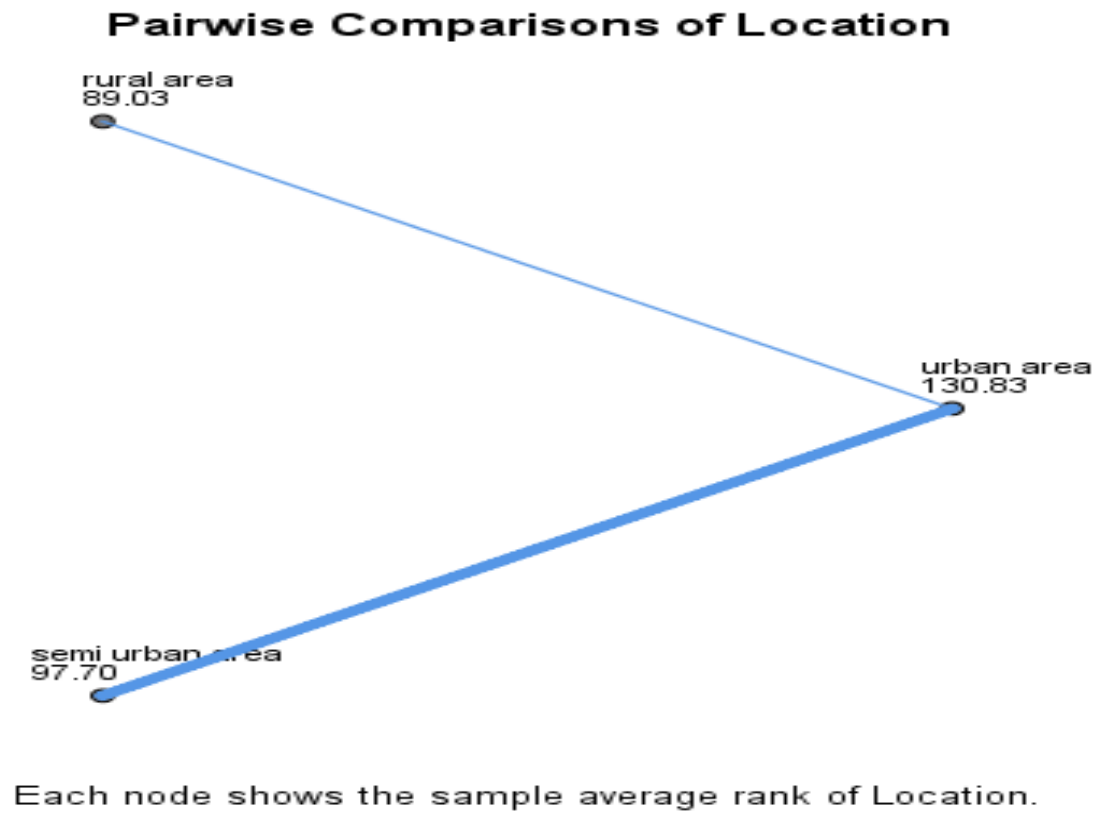

Source: Computed Through SPSS Software.

It has been observed from the above figure $\mathrm{A}$, that mean rank for urban area $(=130.83)$ is much greater than mean rank of rural area $(=89.03)$ and mean rank of semi-urban area $(=97.70)$. Both the mean ranks of rural and semi-urban area differ significantly from mean rank of urban areas per Post Hoc Test result. 
EPRA International Journal of Socio-Economic and Environmental Outlook (SEEO)

ISSN: 2348-4101

Volume: 8 | Issue: 6 | June 2021 | SJIF Impact Factor (2021): 7.426 | Journal DOI: 10.36713/epra0314 | Peer-Reviewed Journal

\section{Descriptive Statistics}

Threat Perception of the Respondents According to their Age Groups in Absolute Figures (Table: 3.1)

\begin{tabular}{|l|c|c|c|c|c|c|}
\hline Age & Very High & High & Moderate & Low & Very Low & Total \\
\hline 15-25 years & 37 & 18 & 11 & 4 & 2 & 72 \\
\hline 25-40 years & 29 & 11 & 6 & 4 & 4 & 54 \\
\hline 40-50 years & 12 & 17 & 5 & 4 & 0 & 38 \\
\hline 50-60 years & 19 & 5 & 8 & 3 & 1 & 36 \\
\hline Above 60 years & 17 & 5 & 6 & 1 & 1 & 30 \\
\hline Total & 114 & 56 & 36 & 16 & 230 \\
\hline
\end{tabular}

Source: Computed by the authors based on data collected through primary survey.

*Threat Perception

From table 3.1 it can be infer that of the total respondents belong to $15-25$ years of age group; 37 have very high, 18 have high, 11 have moderate, 4 have low and 2 have very low threat perceptions. 29 have very high, 11 have high, 6 have moderate, 4 have low and 4 have very low threat perceptions, in case of respondents from 25-40 years of age group. In case of respondents from 40-50 years of age group, 12 have very high, 17 have high, 5 have moderate, 4 have low and 0 have very low threat perceptions. For 50-60 years of age group, 19 have very high, 5 have high, 8 have moderate, 3 have low and 1 have very low threat perceptions. For respondents above 60 years, 17 have very high, 5 have high, 6 have moderate, 1 have low and 1 have very low threat perceptions.

Percentage of Respondents Having Various Degrees of Threat Perception to the Total Numbers of Respondents Coming from Different Age Groups (Table: 3.2 )

\begin{tabular}{|c|c|c|c|c|c|c|}
\hline Age $\quad$ TP* & $\begin{array}{c}\text { Very High } \\
(\%)\end{array}$ & High (\%) & Moderate (\%) & Low (\%) & Very Low (\%) & Total (\%) \\
\hline $15-25$ years & 51.39 & 25 & 15.28 & 5.55 & 2.78 & 100 \\
\hline $25-40$ years & 53.70 & 20.37 & 11.11 & 7.41 & 7.41 & 100 \\
\hline $40-50$ years & 31.58 & 44.74 & 13.16 & 10.52 & 0 & $\varsigma^{\prime} 100$ \\
\hline $50-60$ years & 52.78 & 13.89 & 22.22 & 8.33 & 2.78 & 100 \\
\hline Above 60 years & 56.67 & 16.67 & 20 & 3.33 & 3.33 & 100 \\
\hline
\end{tabular}

Source: Computed by the authors based on data collected through primary survey.

*Threat Perception

It is being observed from the above table 3.2 that of total respondents coming from 15-25 years of age group; $51.39 \%$ have very high, $25 \%$ have high, $15.28 \%$ have moderate, $5.55 \%$ have low and $2.78 \%$ have very low threat perceptions. $53.70 \%$ have very high, $20.37 \%$ have high, $11.11 \%$ have moderate, $7.41 \%$ have low and $7.41 \%$ have very low threat perceptions, in case of respondents from 25-40 years of age group. In case of respondents from $40-50$ years of age group $31.58 \%$ have very high, $44.74 \%$ have high, $13.16 \%$ have moderate, $10.52 \%$ have low and $0 \%$ have very low threat perceptions. For 50-60 years of age group, $52.78 \%$ have very high, $13.89 \%$ have high, $22.22 \%$ have moderate, $8.33 \%$ have low and $2.78 \%$ have very low threat perceptions. For Respondents above 60 years, $56.67 \%$ have very high, $16.67 \%$ have high, $20 \%$ have moderate, $3.33 \%$ have low and $3.33 \%$ have very low threat perceptions. 
Percentage of Respondents Coming from Different Age Groups to the Total Numbers of Respondents Falling Under Different Degrees of Threat Perception (Table: 3.3)

\begin{tabular}{|l|l|l|l|l|l|}
\hline \multicolumn{1}{|c|}{ TP* } & Very High (\%) & High (\%) & Moderate (\%) & Low (\%) & Very Low (\%) \\
\hline $15-25$ years & & & & 25 & 25 \\
\hline $25-40$ years & 25.45 & 32.14 & 30.55 & 25 & 50 \\
\hline $40-50$ years & 10.53 & 19.64 & 16.67 & 25 & 0 \\
\hline $50-60$ years & 16.67 & 30.36 & 13.89 & 18.75 & 12.5 \\
\hline Above 60 years & 14.91 & 8.93 & 22.22 & 6.25 & 12.5 \\
\hline Total $(\%)$ & 100 & 8.93 & 16.67 & 100 & 100 \\
\hline
\end{tabular}

Source: Computed by the authors based on data collected through primary survey.

*Threat Perception

Table 3.3 reveals, of the total respondents having very high threat perception; $32.45 \%$ belongs to $15-25$ years, $19.64 \%$ belongs to $25-40$ years, $10.53 \%$ belongs to $40-$ 50 years, $16.67 \%$ belongs to $50-60$ years and $14.91 \%$ belongs to above 60 years of age group categories. $32.14 \%$ belongs to $15-25$ years, $19.64 \%$ belongs to 25 40 years, $30.36 \%$ belongs to $40-50$ years, $8.93 \%$ belongs to $50-60$ years and $8.93 \%$ belongs to above 60 years of age group categories, of the total respondents having high threat perception. In case of respondents having moderate threat perception; $30.55 \%$ belongs to $15-25$ years, $16.67 \%$ belongs to $25-40$ years, $13.89 \%$ belongs to $40-50$ years, $22.22 \%$ belongs to $50-60$ years and $16.67 \%$ belongs to above 60 years of age group categories. $25 \%$ belongs to $15-25$ years, $25 \%$ belongs to $25-40$ years, $25 \%$ belongs to $40-50$ years, $18.75 \%$ belongs to $50-60$ years and $6.25 \%$ belongs to above 60 years of age group categories, of the total respondents having low threat perception. Out of the total respondents having very low threat perception; 25\% belongs to $15-25$ years, $50 \%$ belongs to $25-40$ years, $0 \%$ belongs to $40-50$ years, $12.5 \%$ belongs to $50-60$ years and $12.5 \%$ belongs to above 60 years of age group categories.

\section{Inferential Statistics:}

The following Null and Alternative Hypothesis has been considered for Analysis

$\mathrm{H}_{02}$ : There is no significant variation in average threat perception based on age groups for general people.

$\mathrm{H}_{12}$ : There is significant variation in average threat perception based on age groups for general people. Analysis:

Table: 3.4

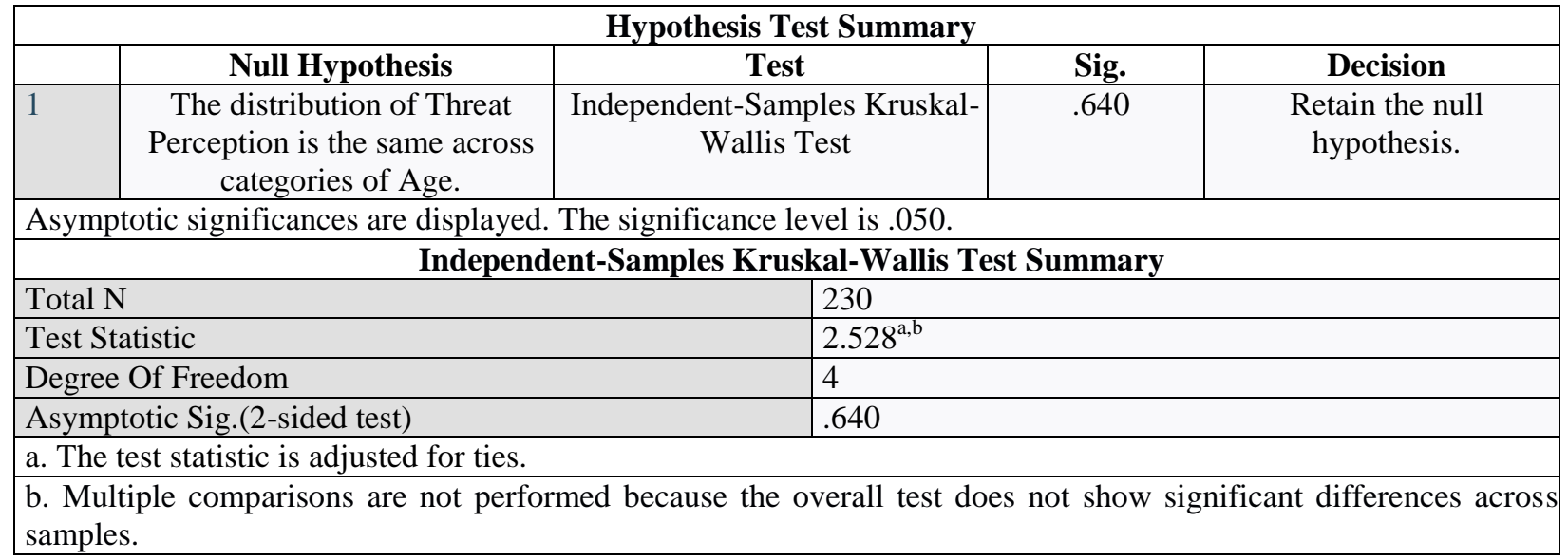

Source: Computed Through SPSS Software.

The table 3.4 in the above reveals that null hypothesis is being accepted at 5\% level of significance and at 4 degree of freedom, with a $\mathrm{P}$ value of .640 ( $\mathrm{P}>.050)$.
Hence there is no significant variation in average threat perception based on age groups for general people. 
EPRA International Journal of Socio-Economic and Environmental Outlook (SEEO)

ISSN: 2348-4101

Volume: 8 | Issue: 6| June 2021 | SJIF Impact Factor (2021): 7.426 | Journal DOI: 10.36713/epra0314 | Peer-Reviewed Journal

Table: 3.5

\begin{tabular}{|l|l|l|l|}
\hline Ranks & \multicolumn{1}{|c|}{ Age } & \multicolumn{1}{c|}{ N } & Mean Rank \\
\hline \multirow{4}{*}{ Threat Perception } & $15-25$ yrs & 72 & 118.82 \\
\cline { 2 - 4 } & $25-40$ yrs & 54 & 117.48 \\
\cline { 2 - 4 } & $40-50$ yrs & 38 & 101.71 \\
\cline { 2 - 4 } & $50-60$ yrs & 36 & 114.81 \\
\cline { 2 - 4 } & above 60 yrs & 30 & 122.27 \\
\cline { 2 - 4 } & Total & 230 & \\
\hline
\end{tabular}

Source: Computed Through SPSS Software.

It can be deciphered from the above table 3.5 that mean rank for $15-25$ years is 118.82 , for $25-40$ years is 117.48 , for $40-50$ years is 101.71 , for $50-60$ years is Descriptive Statistics

Threat Perception of the Respondents According to their Qualifications in Absolute Figures (Table: 4.1)

\begin{tabular}{|l|c|c|c|c|c|c|}
\hline \multicolumn{1}{|c|}{ TP* } & $\begin{array}{c}\text { Very High } \\
(\boldsymbol{\%})\end{array}$ & $\begin{array}{c}\text { High } \\
(\boldsymbol{\%})\end{array}$ & $\begin{array}{c}\text { Moderate } \\
(\boldsymbol{\%})\end{array}$ & $\begin{array}{c}\text { Low } \\
(\boldsymbol{\%})\end{array}$ & $\begin{array}{c}\text { Very Low } \\
(\boldsymbol{\%})\end{array}$ & $\begin{array}{c}\text { Total } \\
(\boldsymbol{\%})\end{array}$ \\
\hline Below class 10 & 12 & 10 & 7 & 5 & 2 & 36 \\
\hline Up to 10th class & 16 & 5 & 5 & 5 & 4 & 35 \\
\hline Up to 12th class & 12 & 7 & 7 & 4 & 1 & 31 \\
\hline Up to Graduation & 44 & 23 & 11 & 1 & 1 & 80 \\
\hline Post-Graduation and above & 30 & 11 & 6 & 1 & 0 & 48 \\
\hline Total (\%) & 114 & 56 & 36 & 16 & 8 & 230 \\
\hline
\end{tabular}

Source: Computed by the authors based on data collected through primary survey.

*Threat Perception

From table 4.1 it can be infer that of the total respondents belong to below class 10 category; 12 have very high, 10 have high, 7 have moderate, 5 have low and 2 have very low threat perceptions. 16 have very high, 5 have high, 5 have moderate, 5 have low and 4 have very low threat perceptions, in case of respondents from up to 10th class category. In case of respondents from up to 12 th class category, 12 have
114.81 and for above 60 years it is 122.27 . Though the mean ranks does not differ statistically. very high, 7 have high, 7 have moderate, 4 have low and 1 have very low threat perceptions. For up to graduation category, 44 have very high, 23 have high, 11 have moderate, 1 have low and 1 have very low threat perceptions. For respondents from postgraduation and above category, 30 have very high, 11 have high, 6 have moderate, 1 have low and 0 have very low threat perceptions.

\begin{tabular}{l} 
Percentage of Respondents Having Various Degrees of Threat Perception to the Total Numbers of \\
Respondents coming from different Qualification Groups (Table: 4.2) \\
\begin{tabular}{|l|c|c|c|c|c|c|}
\hline & $\begin{array}{c}\text { Very High } \\
(\%)\end{array}$ & $\begin{array}{c}\text { Moderate } \\
(\%)\end{array}$ & $\begin{array}{c}\text { Low } \\
(\%)\end{array}$ & $\begin{array}{c}\text { Very Low } \\
(\%)\end{array}$ & $\begin{array}{c}\text { Total } \\
(\%)\end{array}$ \\
& & & & & & \\
\hline
\end{tabular} \\
\hline
\end{tabular}

Source: Computed by the authors based on data collected through primary survey.

*Threat Perception

It is being observed from the above table 4.2 that of total respondents coming from below class 10 category; 
low threat perceptions. $45.71 \%$ have very high, $14.29 \%$ have high, $14.29 \%$ have moderate, $14.29 \%$ have low and $11.43 \%$ have very low threat perceptions, in case of respondents up to 10th class category. In case of respondents up to 12 th class category $38.71 \%$ have very high, $22.58 \%$ have high, $22.58 \%$ have moderate, $12.90 \%$ have low and $3.23 \%$ have very low threat perceptions. For up to graduation category, $55 \%$ have very high, $28.75 \%$ have high, $13.75 \%$ have moderate, $1.25 \%$ have low and $1.25 \%$ have very low threat perceptions. For respondents from post graduation and above category, $62.50 \%$ have very high, $22.92 \%$ have high, $12.5 \%$ have moderate, $2.08 \%$ have low and $0 \%$ have very low threat perceptions.

Percentage of Respondents Coming from different Qualification Groups to the Total Numbers of Respondents Falling under Different Degrees of Threat Perception (Table: 4.3)

\begin{tabular}{|l|c|c|c|c|c|}
\hline Qualification & Very High (\%) & High (\%) & Moderate (\%) & Low (\%) & Very Low (\%) \\
\hline Below class 10 & & & & & \\
\hline Up to 10th class & 10.53 & 17.86 & 19.44 & 31.25 & 25 \\
\hline Up to 12th class & 14.03 & 8.93 & 13.89 & 31.25 & 50 \\
\hline Up to Graduation & 10.53 & 12.5 & 19.44 & 25 & 12.5 \\
\hline Post-Graduation and above & 38.60 & 41.07 & 30.56 & 6.25 & 12.5 \\
\hline Total (\%) & 26.31 & 19.64 & 16.67 & 6.25 & 0 \\
\hline
\end{tabular}

Source: Computed by the authors based on data collected through primary survey.

*Threat Perception

Table 4.3 reveals, of the total respondents having very high threat perception; $10.53 \%$ belongs to below class 10 category, $14.03 \%$ belongs to up to 10 th class category, $10.53 \%$ belongs to up to 12 th class category, $38.60 \%$ belongs to up to graduation category and $26.31 \%$ belongs to post graduation and above category. $17.86 \%$ belongs to below class 10 category, $8.93 \%$ belongs to up to 10 th class category, $12.5 \%$ belongs to up to 12 th class category, $41.07 \%$ belongs to up to graduation category and $16.67 \%$ belongs to above 60 years of age group category, of the total respondents having high threat perception. In case of respondents having moderate threat perception; $19.44 \%$ belongs to below class 10 category, $13.89 \%$ belongs to up to 10th class category, $19.44 \%$ belongs to up to 12 th class category, $30.56 \%$ belongs to up to graduation category and $16.67 \%$ belongs to above 60 years of age group category. $31.25 \%$ belongs to below class 10 category, $31.25 \%$ belongs to up to 10th class category, $25 \%$ belongs to up to 12 th class category, $6.5 \%$ belongs to up to graduation category and $6.5 \%$ belongs to above 60 years of age group category, of the total respondents having low threat perception. Out of the total respondents having very low threat perception; $25 \%$ belongs to below class 10 category, $50 \%$ belongs to up to 10 th class category, $12.5 \%$ belongs to up to 12 th class category, $12.5 \%$ belongs to up to graduation category and $0 \%$ belongs to above 60 years of age group category.

\section{Inferential Statistics}

The following Null and Alternative Hypothesis has been considered for Analysis

$\mathrm{H}_{03}$ : There is no significant variation in average threat perception based on qualification categories for general people.

$\mathrm{H}_{13}$ : There is significant variation in average threat perception based on qualification categories for general people.

Analysis:

Table: 4.4

\begin{tabular}{|l|c|c|c|c|}
\hline \multicolumn{5}{|c|}{ Hypothesis Test Summary } \\
\hline 1 & Null Hypothesis & Test & Sig. & Decision \\
\hline & $\begin{array}{c}\text { The distribution of Threat } \\
\text { Perception is the same across } \\
\text { categories of Educational } \\
\text { Qualification. }\end{array}$ & $\begin{array}{c}\text { Independent-Samples Kruskal- } \\
\text { Wallis Test }\end{array}$ & .003 & $\begin{array}{c}\text { Reject the null } \\
\text { hypothesis. }\end{array}$ \\
\hline \multicolumn{2}{|c|}{ Asymptotic significances are displayed. The significance level is .050. } \\
\hline
\end{tabular}


EPRA International Journal of Socio-Economic and Environmental Outlook (SEEO)

ISSN: 2348-4101

Volume: 8 | Issue: 6| June 2021 | SJIF Impact Factor (2021): 7.426 | Journal DOI: 10.36713/epra0314 | Peer-Reviewed Journal

Independent-Samples Kruskal-Wallis Test Summary

\begin{tabular}{|l|l|}
\hline Total N & 230 \\
\hline Test Statistic & $16.129^{\mathrm{a}}$ \\
\hline Degree Of Freedom & 4 \\
\hline Asymptotic Sig.(2-sided test) & .003 \\
\hline a. The
\end{tabular}

a. The test statistic is adjusted for ties.

Source: Computed Through SPSS Software.

The above table reveals that null hypothesis is being rejected at $5 \%$ level of significance and at 4 degree of

Post Hoc Test

freedom, with a $\mathrm{P}$ value of $.003(\mathrm{P}<.050)$. Hence there is significant variation in average threat perception based on qualification categories for general people.

Table: 4.5

\begin{tabular}{|c|c|c|c|c|c|}
\hline \multicolumn{6}{|c|}{ Pairwise Comparisons of Educational Qualification } \\
\hline Sample 1-Sample 2 & Test Statistic & Std. Error & Std. Test Statistic & Sig. & Adj. Sig. ${ }^{a}$ \\
\hline $\begin{array}{l}\text { below class } 10 \text {-upto class } 12 \\
\text { (Uchya madhyamik) }\end{array}$ & -5.794 & 15.116 & -.383 & .701 & 1.000 \\
\hline $\begin{array}{l}\text { below class 10-upto class } 10 \\
\text { (Madhyamik) }\end{array}$ & -7.678 & 14.644 & -.524 & 600 & 1.000 \\
\hline below class 10 -upto graduation & -33.753 & 12.381 & -2.726 & .006 & .064 \\
\hline $\begin{array}{l}\text { below class } 10 \text {-post graduation } \\
\text { and above }\end{array}$ & -41.153 & 13.602 & -3.026 & .002 & .025 \\
\hline $\begin{array}{l}\text { upto class } 12 \text { (Uchya } \\
\text { madhyamik)-upto class } 10 \\
\text { (Madhyamik) }\end{array}$ & 1.884 & 15.215 & .124 & .901 & 1.000 \\
\hline $\begin{array}{l}\text { up to class } 12 \text { (Uchya } \\
\text { madhyamik)-upto graduation }\end{array}$ & -27.959 & 13.052 & -2.142 & .032 & .322 \\
\hline $\begin{array}{l}\text { upto class } 12 \text { (Uchya } \\
\text { madhyamik)-post graduation and } \\
\text { above }\end{array}$ & -35.359 & 14.215 & -2.487 & .013 & .129 \\
\hline $\begin{array}{l}\text { upto class } 10 \text { (Madhyamik)-upto } \\
\text { graduation }\end{array}$ & -26.075 & 12.503 & -2.086 & .037 & .370 \\
\hline $\begin{array}{l}\text { upto class } 10 \text { (Madhyamik)-post } \\
\text { graduation and above }\end{array}$ & -33.475 & 13.712 & -2.441 & .015 & .146 \\
\hline $\begin{array}{l}\text { upto graduation-post graduation } \\
\text { and above }\end{array}$ & -7.400 & 11.263 & -.657 & .511 & 1.000 \\
\hline
\end{tabular}

Each row tests the null hypothesis that the Sample 1 and Sample 2 distributions are the same.

Asymptotic significances (2-sided tests) are displayed. The significance level is .05.

a. Significance values have been adjusted by the Bonferroni correction for multiple tests.

Source: Computed Through SPSS Software.

It is being observed from the above Table 2.5 that after adjusting the significance values through Bonferroni correction for multiple tests, the statistically significant differences in mean threat perception exists between below class 10 category and post-graduation and above category. The adjusted $\mathrm{P}$ value is .025 and the value is less than .050 . No statistically significant differences exist in other combinations. 


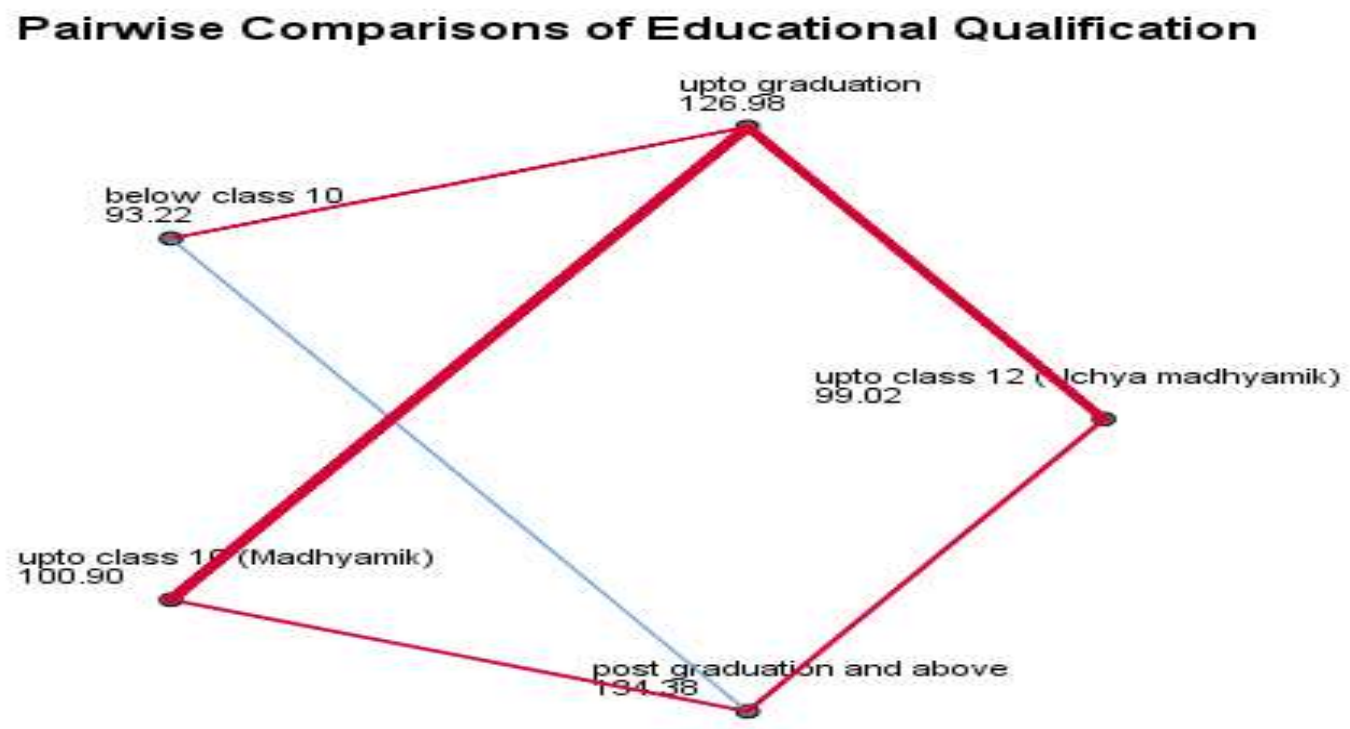

Each node shows the sample average rank of Educational Qualification.

Source: Computed Through SPSS Software.

From figure $\mathrm{B}$ it can be deciphered that mean rank for below class 10 category is 93.22 , up to class 10 is 100.90 , up to class 12 is 99.02 , up to graduation is 126.98 and finally for post-graduation and above is 134.38.The mean rank for post-graduation and above category $(=134.38)$ is much higher than mean rank for below class 10 category $(=93.22)$ and also statistically differ as per Post Hoc Test result.

Now the researchers conducted the Ordinal Logistic Regression for understanding how far independent variables having significant correlation with dependent variable, can explain the change or variation of it and how far the developed model for prediction is full proof.

\section{Inferential Statistics}

Analysis:

$\mathrm{H}_{04}$ : The regression model does not provide good prediction of the outcomes.

$\mathrm{H}_{14}$ : The regression model provides good prediction of the outcomes.

Table: 5.1

\begin{tabular}{|l|l|l|l|l|}
\hline \multicolumn{5}{|c|}{ Model Fitting Information } \\
\hline Model & -2 Log Likelihood & Chi-Square & df & Sig. \\
\hline Intercept Only & 188.086 & & & \\
\hline Final & 156.708 & 31.378 & 6 & .000 \\
\hline Link function: Logit.
\end{tabular}

Source: Computed Through SPSS Software.

It is observed from above table 5.1 that statistically significant Chi-Square statistic has been obtained or null hypothesis got rejected with $\mathrm{P}=.000(\mathrm{P}<.05)$. It tells that the model is very good in predicting the outcomes or dependent variable.

Analysis: 
EPRA International Journal of Socio-Economic and Environmental Outlook (SEEO)

ISSN: 2348-4101

Volume: 8 | Issue: 6 | June 2021 | SJIF Impact Factor (2021): 7.426 | Journal DOI: 10.36713/epra0314 | Peer-Reviewed Journal

$\mathrm{H}_{05}$ : The predicted values are consistent with observed values for the regression model.
$\mathrm{H}_{15}$ : The predicted values are not consistent with observed values for the regression model.

Table: 5.2

\begin{tabular}{|l|c|c|c|}
\hline \multicolumn{4}{|c|}{ Goodness-of-Fit } \\
\hline Pearson & Chi-Square & df & Sig. \\
\hline Deviance & 49.162 & 50 & .507 \\
\hline Link function: Logit. & 56.575 & 50 & .243 \\
\hline
\end{tabular}

Source: Computed Through SPSS Software.

Based on the information provided in the above table it can be infer that both the Chi-Square statistics has been accepted with $\mathrm{P}=.507(\mathrm{P}<.05)$ and $\mathrm{P}=.243(\mathrm{P}<.05)$ for Pearson and Deviance respectively or null hypothesis got accepted. It means the data has been fitted excellently in the model and there is insignificant deviation between observed values and predicted values, predicted by the model.

Table: 5.3

\begin{tabular}{|l|c|}
\hline \multicolumn{2}{|c|}{ Pseudo R-Square } \\
\hline Cox and Snell & .128 \\
\hline Nagelkerke & .138 \\
\hline McFadden & .053 \\
\hline Link function: Logit. & \\
\hline
\end{tabular}

Source: Computed Through SPSS Software.

The above table 5.3 reveals that $13.8 \%$ of the variation in the threat perception can be explained jointly by two demographic factors namely, place of stay of the people and educational qualifications of the people.
$\mathrm{H}_{06}$ : The location parameters (slope coefficients) are the same across response categories.

$\mathrm{H}_{16}$ : The location parameters (slope coefficients) are not same across response categories.

Table: 5.4

\begin{tabular}{|l|c|c|c|c|}
\hline \multicolumn{5}{|c|}{ Test of Parallel Lines $^{\mathbf{a}}$} \\
\hline Model & -2 Log Likelihood & Chi-Square & df & Sig. \\
\hline Null Hypothesis & 156.708 & & & \\
\hline General & 130.468 & 26.240 & 18 & .094 \\
\hline
\end{tabular}

The null hypothesis states that the location parameters (slope coefficients) are the same across response categories.

a. Link function: Logit.

Source: Computed Through SPSS Software.

Here the null hypothesis got accepted with a high $\mathrm{P}$ value of .094 ( $\mathrm{P}>$.050) hence the overall predictive capacity of the model is very good, that is ordered logit coefficients are equal across all the levels of outcome and thus the model is sufficient. Thus it also signify excellent fitting of the model.

\section{DISCUSSIONS AND CONCLUSIONS}

1. It has been obtained from the above analysis that threat perception of the general individuals vary significantly in respect to place of stay. Urban people have comparatively much higher threat perception regarding impact of Corona on human health than semi-urban and rural people. General human perception regarding how much an individual will feel threat regarding impact of a disease on human health depends on two main factors, one is the chance of getting infected by the disease by that individual and another is amount of knowledge about that disease accessed by that individual. Whenever an individual being asked about how much he perceived about the threat 
from a particular thing on human being, he will first of all judge it based on the threat he himself or she herself feel in regards to him or her, respectively from that thing. The validness of these two ideas has been highly supported by the views of respondents encountered by the researchers during the sample collections. Firstly, the major impact of the current pandemic is basically urban area and megacity area oriented. If the concentration of the disease all over the world can be thoroughly analyzed, it can be easily inferred that major cities and urban centers of the world are worst impacted. The diseases is extremely contagious and hence economic epicenters of the world from where large number of persons from all over the world moves in and large number of person goes to different parts of the world for mainly economic purposes are becoming disease epicenters and also helping in its spread. In urban areas, especially in urban slums peoples live in very close proximity and that is another reason for rapid spread of the disease. The rural and semiurban areas are not so much economically active like urban centers and hence spread of virus is not very threatening here. The megacities of India like Mumbai, Delhi, Chennai, and Kolkata are best examples of disease epicenters. Researchers have find that in urban areas office goers are ready to pay double the normal fare for small and medium passenger vehicles to reduce passengers in those vehicles. The rural and semi-urban areas of India bear much less burn from the current pandemic, though movement of migrant laborers worsen the situation some extant but not as cities, where community spreading is evidential in some areas. For all this urban people are at more risk from the current pandemic than rural people, due to this they have higher threat perception. Secondly there is higher rate of dissemination of information and news regarding current virus in urban areas than in rural and semi-urban areas as urban people are more active in social media and are more tech savvy. In the current context in India, the way in which the infection rises in urban centers; most of that information are de-motivating in nature and sometimes are also rumors.

2. It has been observed from the above analysis that age of the people has no significant on threat perceptions of the general public in the country. The disease is extremely contagious and has a wide rich to all the people irrespective of their ages, as evidenced from the various news reports.
Moreover it is hard to predict that to what extent the virus will impact an individual. Scientists and medical researchers have pointed out that virus has different strains and each strain has different impact on different individuals based on their genitival get up. Researchers through their sample collection understand that most of the general public irrespective of their ages have believe in the above facts. Though many researchers have pointed out that virus impact more the aged populations, as they have more chance of having co-morbidities. When the researchers interviewed individuals, most individuals claimed that due to their practical experience they don't believe in it too much. Hence the perception does not vary with age.

3. The analysis shows that significant difference in mean perception exists between two sub-groups of educational qualifications and no other combinations of sub-groups have statistically significant different means. Hence education is also a vital factor in defining threat perception. From here it can infer that very high educational background and conversely very poor educational background are deciding factor The people with very high educational backgrounds have very high threat perception, whereas people with very poor educational backgrounds have a very low threat perception. The people with higher qualifications have more detailed idea about the nutty gritty of the disease, they have much more information reach than people with lower educational qualifications, as they can more easily access various communication tools and technologies. In the current situation when daily infections are rising at an alarming rate in the urban areas, scientists are unable to give any clear view about the futuristic trend and features of the disease, different strains of the virus has different severity and maximum educated populations are concentrated in the urban areas, the threat perception of highly qualified personals are really high. The researchers identified above factors based on communications with the respondents during sample collections. The people of lower educational qualifications are basically illiterate people, like maids, laborers and sellers of grocery products in the market, through the sample survey researchers understand that they have very negligible idea regarding the disease and for which their threat perception is low. Another solid ground that researchers get to know through sample survey 
is, poor and daily earners said they are bound to go for work for meeting their daily meals and so if they stay inside their houses for fear it will of no meaning to them.

4. It has been excellently observed from the analysis that the regression model fits very well with the data set and also has high predictive capacity. The variation of dependent variable has been explained just $13.8 \%$. The value of explaining percentage is low because the researchers have only taken two independent variables in developing the model. There are many other factors that are responsible for defining threat perception like, health condition, Job attached with, etc.

Finally it can be concluded that people with higher educational reach and people living in urban areas have higher threat perception, than people living in rural and semi-urban areas and people with poor educational reach. Now urban based people are basically more educated than semi-urban and rural people and hence the perception variance follows a well-defined logical trend.

\section{Recommendations}

Based on the above discussions and conclusions following recommendations are drawn.

1. Firstly, it has been clearly observed that urban area has much higher threat perception than rural and semi-urban area and for this there are huge self or family imposed restrictions on free movement of individuals. For this, one hand the businesses and shops will face huge shortage in daily footfall. Recently it has been reported in a leading newspaper that though Gariahat market started to operate, but customer footfall is very low. These problems are more acute for MSME traders like hawkers and small and medium retail shop owners who don't have state of the art sanitization facilities and idea. General urban customers having very high threat perceptions are avoiding unnecessary purchase and especially from road shops and small shops, as also large malls are started to open up. This direct impact on economic activities of the country is an after effect of this continuing pandemic and it will probably continue for long. On other hand various persons working in different places, who have either returned to their place of origin or sitting idle in their houses feel high threat in joining their works at urban areas and in several rural areas the local people has decided not to allow their local people from going to urban areas for job purpose, researchers have learnt this from the respondents through their questioning session. It has recently being reported in a leading Bengali daily that though Bengal government has asked to run public offices at $70 \%$ employee load, but in real life most of the employees did not join the work. Here also a threat perception works, probably apart from transport problems. The state and central authorities need to spread proper awareness and guidance in a large and rapid scale in urban areas to alleviate the threat perception of the general urban public and also need to make them aware about how to take protection against it. The strict necessary actions need to be taken against the spread of rumor. These measures are very urgent in giving required lost force in urban economic activities. In case of urban and semi-urban areas though threat perception is comparatively less, but one thing need to be ensured that rapid spread of disease should not be entertained in any way due to lack of awareness regarding the disease. The low to moderate threat perception will not deter people too much from joining daily economic activities. Again due to less per capita income in rural and semi-urban areas than urban areas; people are more eager to join work. There is a high chance of infection spread through economic activities in those areas, as governments has already allowed opening of most of the economic activities. The return of migrant laborers in their homes, especially in rural and semi-urban areas started to make those places pandemic hotspots. So, if in the current scenario the spread of disease being boost up by low threat perception due to lack of awareness and poor initial spread of disease in those areas; there will be a huge shock on both social and economic life of individuals. The authorities need to spread adequate awareness in those areas regarding the threat of disease and how to tackle it in the work places. So that socioeconomic backbone of the country can be bring back to square one. To ensure fulfillment of both economic and health goals, governments and private organizations in India need to promote "work from home" idea as far as feasible. 
2. From the analysis it has been deciphered that people with very high educational qualifications have comparatively very high threat perception. Their higher threat perception will obviously impact their free movement. This people are basically falls within moderate to high income groups and self-imposed restrictions on their movements induced them using of e-commerce sites in procuring necessary items. This seriously impacted good, wealthy and consistent customer bases of various physical shops dealing in necessary and luxury good items. Hospitality and service industries having a major portion of service seekers in this category are also impacted seriously for this. Due to preexisting hygiene issue and present situation creates a gigantic problem for road side and roaming vendors dealing in various food items to sell their foods, even office goers who earlier purchased foods from those shops are taking food from their houses. The researchers develop these facts by interviewing several vegetable sellers, parlor operators, hotels, decorating and gift items shop owners and office goers. The economic activities to which they are attached are not so much impacted as they can work from home. Though they are very much aware about the disease, still governments need to spread required awareness among them, so that they purchase both necessary and consumer durable articles from physical shops. Because the spread of disease can be contained to a large extent if proper precautions can be taken. The owners of physical shops are mainly MSMEs, current situational adversaries will give them huge shock unless and until threat perception of wealthy customers alleviate. E-commerce businesses have negligible share in employment creation in India and this are mainly capital and technology intensive MNCs. They have capacity to absorb shocks, unlike MSMEs. The persons with very low educational background, like workers, maids, rickshaw pullers and auto drivers, etc., have very low threat perception. Their low threat perception due to lack of awareness can be fatal for them sometimes. In the current period and in the immediate future; it is clearly visible and predictable respectively that disease is spreading at a rapid pace. Down trodden peoples are bound to travel various places for search of various works with minimum or no precautions. So, they have high chance of getting infected in this peak time and they are also basically with low immunity due to poor standard of living. If this people get infected due to low awareness, it will be a massive blow to both their social and economic life. They are basically daily earners and have moderate to large families to look after. Researchers during their sample collection observed that various maid servants lost their jobs, as several cases of infections are due to them. They said highly educated people employing them for long remove them from their jobs permanently, saying they will be called if required and they are posing high chance of spreading infections. Government authorities and educated individuals need to spread required awareness regarding the disease among them and need to provide them financial and non-financial support to sustain their livelihood under current situation in a healthy condition.

Every pandemic has a huge shock impact on general public and develop a long lasting fear psychosis among them. This prevents them from joining normal life. General public need to current pandemic is not at all fatal, through proper precautions and knowledge it can be easily avoided and there is no meaning in hampering economic activities of the country for this wrong threat perception. The every government needs to take definite courses of actions in this point of time for reengineering the general economic activities, apart from tackling the event through spreading desired awareness and by providing desired services.

\section{Limitations and Future Research Scope}

Researchers conducted the present study based on some selected numbers of independent variables. There are many independent variables that can impact the threat perception of general public has not been included in the current study. Again, as the study based on selected number of independent variables; hence Factor Analysis tools have not been used by the researcher in understanding the main factors behind variation in the threat perception. Moreover, the sample has been collected from few locations of the few states. Future research in this area will have huge socioeconomic significance if can be conducted by considering large number of logical variables. The sample selection should also need to be more full proof 
EPRA International Journal of Socio-Economic and Environmental Outlook (SEEO)

ISSN: 2348-4101

Volume: 8 | Issue: 6 | June 2021 | SJIF Impact Factor (2021): 7.426 | Journal DOI: 10.36713/epra0314 | Peer-Reviewed Journal

and planned. Further, there are many options in selecting statistical tools for analysis and this has to be considered logically.

\section{REFERENCES}

1. Bavel, J., Baiker, K. \&Willer, R. (2020). Using social and behavioural science to support COVID19 pandemic response. Nature Human Behavior. 4, 460-471.

2. Chatterjee, K., Kumar, A. \& Shankar, S. (2020): Healthcare impact of COVID-19 epidemic in India: A stochastic mathematical model.Medical journal Armed Forces India.76 (2), 147-155.

3. Das, S. (2018). Health and sanitation conditions in rural India-An overall study. Asian Journal of Multidimensional Research (AJMR), 7(8), 266-280.

4. Das, S., Basak, S., \& Das, G. M. (2020). A Study for Understanding the Problems of MSMEs under Current Pandemic Situation with Special Reference to Kolkata.The Management Accountant Journal, 55(12), 65-67.

5. De, P. (2020). COVID-19, New Normal and India. EEPCINDIA. 1, 89-94.

6. Dev, S. \& Sengupta, R. (2020). Covid-19: Impact on the Indian Economy. Indira Gandhi Institute of Development Research.WP-2020-013.

7. Gupta, R. P. (2020). Covid-19 and India's Foreign Trade: An Empirical Analysis of Select Commodities. EPRA International Journal of Research and Development (IJRD), 5(7), 229-307.

8. Khetrapal, S. \& Bhatia, R. (2020): Impact of COVID-19 pandemic on health system \& Sustainable Development Goal 3. Indian Journal of Medical Research. 151.

9. Mathur, S. (2020). What Causes COVID-19 Spread: Cross-country Evidence with Focus on India. EEPCINDIA. 1, 95-100.

10. Raychaudhari, A. (2020). COVID-19 Pandemic Crisis and the Way Forward for India. EEPCINDIA. 1, 9-12.

11. Singhal, A. (2020). Responding to the COVID-19 Crisis: Policy Priorities for India. EEPCINDIA. 1, 101-104.

12. Udwadia, Z. \& Raju, R. (2020). How to protect the protectors: 10 lessons to learn for doctors fighting the COVID-19 coronavirus. Medical journal Armed Forces India. 76(2), 128-131.

13. Zhang, Y. \& Ma, Z. (2020). Impact of the COVID19 Pandemic on Mental Health and Quality of Life among Local Residents in Liaoning Province, China: A Cross-Sectional Study. International Journal Environ Res Public Health, 17(7).

14. https://economictimes.indiatimes.com/blogs/cursor/ coronavirus-both-a-threat-and-opportunity-forindial

15. https://indianexpress.com/article/opinion/indiacoronavirus-lockdown-how-framing-the-covid- numbers-changes-individuals-risk-perception6426819/

16. https://www.cii.in/publications.aspx

17. https://www.weforum.org/agenda/2020/03/covid19-public-perception-economic-health-crisiscoronavirus-pandemic-ipsos/

18. https://www.who.int/bulletin/online_first/20255695.pdf 